\title{
Carbon dioxide dynamics in an agricultural headwater stream driven by hydrology and primary production
}

\author{
Marcus B. Wallin ${ }^{1,2}$, Joachim Audet ${ }^{3}$, Mike Peacock ${ }^{1}$, Erik Sahlée ${ }^{2}$, and Mattias Winterdahl ${ }^{2,4,5}$ \\ ${ }^{1}$ Department of Aquatic Sciences and Assessment, Swedish University of Agricultural Sciences, Uppsala, Sweden \\ ${ }^{2}$ Department of Earth Sciences, Uppsala University, Uppsala, Sweden \\ ${ }^{3}$ Department of Bioscience, Aarhus University, Silkeborg, Denmark \\ ${ }^{4}$ Department of Physical Geography, Stockholm University, Stockholm, Sweden \\ ${ }^{5}$ Bolin Centre for Climate Research, Stockholm, Sweden
}

Correspondence: Marcus B. Wallin (marcus.wallin@slu.se)

Received: 13 December 2019 - Discussion started: 29 January 2020

Revised: 2 April 2020 - Accepted: 6 April 2020 - Published: 8 May 2020

\begin{abstract}
Headwater streams are known to be hotspots for carbon dioxide $\left(\mathrm{CO}_{2}\right)$ emissions to the atmosphere and are hence important components in landscape carbon balances. However, surprisingly little is known about stream $\mathrm{CO}_{2}$ dynamics and emissions in agricultural settings, a land use type that globally covers ca. $40 \%$ of the continental area. Here we present hourly measured in situ stream $\mathrm{CO}_{2}$ concentration data from a $11.3 \mathrm{~km}^{2}$ temperate agricultural headwater catchment covering more than 1 year (in total $339 \mathrm{~d}$ excluding periods of ice and snow cover). The stream $\mathrm{CO}_{2}$ concentrations during the entire study period were generally high (median $3.44 \mathrm{mg} \mathrm{C} \mathrm{L}^{-1}$, corresponding to partial pressures $\left(p \mathrm{CO}_{2}\right)$ of $\left.4778 \mu \mathrm{atm}\right)$ but were also highly variable ( $\left.\mathrm{IQR}=3.26 \mathrm{mg} \mathrm{C} \mathrm{L}^{-1}\right)$. The $\mathrm{CO}_{2}$ concentration dynamics covered a variety of different timescales from seasonal to hourly, with an interplay of hydrological and biological controls. The hydrological control was strong (although with both positive and negative influences dependent on season), and $\mathrm{CO}_{2}$ concentrations changed rapidly in response to rainfall and snowmelt events. However, during growing-season base flow and receding flow conditions, aquatic primary production seemed to control the stream $\mathrm{CO}_{2}$ dynamics, resulting in elevated diel patterns. During the dry summer period, rapid rewetting following precipitation events generated high $\mathrm{CO}_{2}$ pulses exceeding the overall median level of stream $\mathrm{CO}_{2}$ (up to 3 times higher) observed during the whole study period. This finding highlights the importance of stream intermittency and its effect on stream $\mathrm{CO}_{2}$ dynamics. Given the observed high levels of $\mathrm{CO}_{2}$ and its temporally variable na-
\end{abstract}

ture, agricultural streams clearly need more attention in order to understand and incorporate these considerable dynamics in large-scale extrapolations.

\section{Introduction}

Fluvial systems (streams and rivers) are estimated to dominate the inland water $\mathrm{CO}_{2}$ source globally, surpassing $\mathrm{CO}_{2}$ emissions from lakes and reservoirs by a factor of 6 (Raymond et al., 2013). However, this estimate relies on a number of assumptions, and the scarcity of empirical data makes it uncertain. One of the critical gaps in the global upscaling is the lack of direct measurements from agriculture-dominated areas (Osborne et al., 2010). Globally, agricultural land covers about $40 \%$ of the total continental area (Ramankutty et al., 2008), but there are few studies specifically focusing on the magnitude and dynamics of $\mathrm{CO}_{2}$ emissions from agricultural streams. The few studies that do exist have shown that agricultural stream $\mathrm{CO}_{2}$ concentrations are generally high and up to 5 times greater than those in streams draining forested areas which are more extensively studied (Borges et al., 2018; Bodmer et al., 2016; Wallin et al., 2018). For example, Bodmer et al. (2016) measured partial pressure of $\mathrm{CO}_{2}$ $\left(p \mathrm{CO}_{2}\right)$ in German and Polish streams and examined differences between forested and agricultural catchments. They found that $p \mathrm{CO}_{2}$ was generally 2-3 times higher in agricultural streams compared to streams draining forested areas. Similarly, Borges et al. (2018) found high $\mathrm{CO}_{2}$ concentra- 
tions in streams and rivers dominated by agriculture in the river system Meuse, Belgium. They linked the higher $p \mathrm{CO}_{2}$ in agricultural streams to elevated levels of dissolved organic carbon (DOC), particulate organic carbon (POC) and inorganic nitrogen. On the other hand, Deirmendjian et al. (2019) showed that there was no difference in $p \mathrm{CO}_{2}$ between forest and cropland streams in south-west France despite higher $p \mathrm{CO}_{2}$ in forest groundwater compared to cropland groundwater. They explained the similar stream $p \mathrm{CO}_{2}$ by more efficient gas exchange in the forest streams compared to the low-gradient cropland streams.

There are numerous factors influencing $\mathrm{CO}_{2}$ patterns in stream systems, and site-specific controls often dominate. Hence, large-scale generalizations are difficult to make (Crawford et al., 2017). Based on high-frequency data, $\mathrm{CO}_{2}$ concentrations in streams draining nutrient-poor forest and peatlands, as well as tropical forests, are often found related to variations in stream discharge but with site-specific response patterns, with $\mathrm{CO}_{2}$ found to be either positively or negatively related to stream discharge (Crawford et al., 2017; Dinsmore et al., 2013; Johnson et al., 2007). These response patterns have often been connected to the catchment characteristics and changes in hydrological pathways, which in turn control the dominant source areas (both from a vertical and lateral point of view) of $\mathrm{CO}_{2}$ in the catchment soils (Campeau et al., 2018; Leith et al., 2015; Dinsmore and Billett, 2008). In contrast, other catchments lack a strong hydrological control and instead display clear diel cycles in stream $\mathrm{CO}_{2}$ concentration, indicating a metabolic control (Crawford et al., 2017). Here the interplay of photosynthesis and respiration (in stream or terrestrial) could result in large day- to night-time differences in stream $\mathrm{CO}_{2}$.

These recent findings concerning dynamics and controls on stream $\mathrm{CO}_{2}$ concentrations have been possible due to the development of cost-effective $\mathrm{CO}_{2}$ sensors (e.g. Johnson et al., 2010; Bastviken et al., 2015) which have enabled continuous data collection covering relevant timescales $(<$ hourly resolution). However, very little information about stream $\mathrm{CO}_{2}$ dynamics exists from agricultural areas, a land use type that is heavily managed by humans, including hydrological drainage, nutrient additions, soil cultivation, etc. As a consequence, $\mathrm{CO}_{2}$ patterns in agricultural streams could potentially be very different than in other land use types with amplified diel $\mathrm{CO}_{2}$ dynamics due to high metabolism and/or quicker response to hydrological events due to effective drainage systems.

In addition to the concentration gradient between the stream water and the air above, gas exchange is also highly dependent on the physical conditions at the air-water interface. For stream systems, the gas transfer velocity (often the variable given to describe the efficiency of the air-water gas exchange) is related to a combination of hydrological and morphological conditions of the stream channel, often including slope, velocity, and water depth (Raymond et al., 2012; Wallin et al., 2011). All these variables are proxies for describing the turbulence of the stream water, which controls the gas exchange but is rarely directly measured (Kokic et al., 2018). Agricultural areas are often located in flat landscapes, resulting in drainage systems that have a low gradient and are slow-flowing (Rhoads et al., 2003; Hughes et al., 2010), conditions that prevent effective air-water gas exchange (Hall and Ulseth, 2019). However, whether the elevated $p \mathrm{CO}_{2}$ observed in agricultural streams is an effect of land-use-specific hydro-morphological stream conditions preventing efficient gas exchange or an effect of high internal (aquatic) or external (terrestrial) $\mathrm{CO}_{2}$ production is currently unknown.

Although recent studies have identified agricultural streams as high- $p \mathrm{CO}_{2}$ systems, there are still large knowledge gaps to be filled in order to improve our understanding concerning the influence of these waterbodies in landscape $\mathrm{C}$ cycling. Here we present high-resolution (hourly) $\mathrm{CO}_{2}$ concentration measurements in a Swedish agricultural headwater stream for more than a year (in total $339 \mathrm{~d}$ excluding periods of ice and snow cover). The study aimed to (1) quantify $\mathrm{CO}_{2}$ concentration levels in an agricultural stream and explore its temporal dynamics and (2) identify the main drivers causing temporal variability in stream $\mathrm{CO}_{2}$ concentration and how they might vary with season.

\section{Methods}

\subsection{Study area}

The study was conducted within the $11.3 \mathrm{~km}^{2}$ Sundbromark $(\mathrm{SBM})$ catchment $\left(59^{\circ} 55^{\prime} \mathrm{N}, 17^{\circ} 32^{\prime} \mathrm{E}\right)$, located $5 \mathrm{~km} \mathrm{NW}$ of the city of Uppsala, Sweden (Fig. 1b). The catchment is a part of the hydro-meteorological observatory Marsta that was established in the late 1940s (Halldin et al., 1999). The 30-year (1960-1991) mean annual temperature for the area is $5.3^{\circ} \mathrm{C}$ (mean January and July temperatures are -4.5 and $16.0^{\circ} \mathrm{C}$, respectively) and with a mean annual precipitation of $535 \mathrm{~mm}$. The length of the growing season is on average ca. $210 \mathrm{~d}$ from early April to the end of October (Swedish Meteorological and Hydrological Institute, SMHI). The catchment is dominated by agricultural land $(86 \%)$ mainly used for cereal production and pasture, and with minor influence of forest $(8 \%)$ and urban areas $(6 \%)$. The area is flat with only $28 \mathrm{~m}$ elevation difference from $41 \mathrm{~m}$ a.s.l. at the highest point to $13 \mathrm{~m}$ a.s.l. at the catchment outlet (Table 1). The bedrock consists of gneissic granites, and the soils are dominated by post-glacial clay at lower elevations and with some influence of glacial clay and silt at higher elevations. Although the bedrock does not contain any known carbonates, the soils are alkaline due to glacial-carbonatecontaining deposits, resulting in a stream $\mathrm{pH}$ ranging between 7.4 and 8.4 (Table 2), and with high electrical conductivity (EC, 791-1908 $\mu \mathrm{S} \mathrm{cm}^{-1}$ ) (Osterman, 2018). The nutrient and DOC levels of the stream water (Table 1) are at the lower end (within the 25th percentile) of monitored agri- 


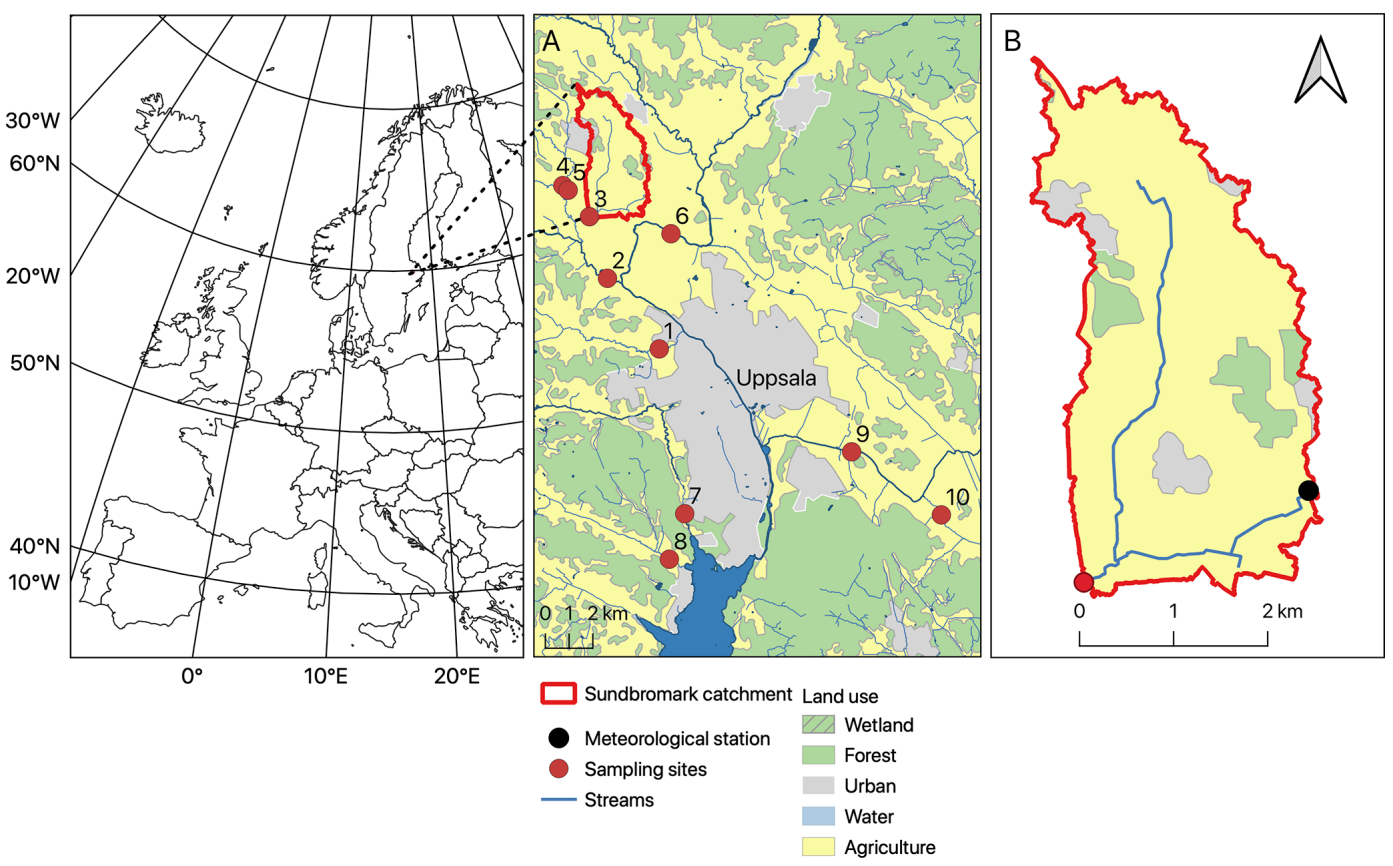

Figure 1. Location of the study with (a) sampled sites of the spatial survey and (b) the Sundbromark (SBM) catchment. Catchment delineation and land use distributions are given according to GSD elevation data, grid 2+ (@Swedish Land Survey) and CORINE Land Cover 2018 (European Environment Agency).

Table 1. Catchment characteristics of the Sundbromark (SBM) catchment.

\begin{tabular}{lr}
\hline Catchment area $\left(\mathrm{km}^{2}\right)$ & 11.3 \\
Elevation range (ma.s.l.) & $13-41$ \\
\hline Land use distribution (\%) & \\
\hline Agricultural land & 86 \\
Forest & 8 \\
Urban & 6 \\
\hline Main soil type distribution $(\%)$ & \\
\hline Post-glacial clay & 48 \\
Glacial silt & 22 \\
Glacial clay & 14 \\
Sandy till & 12 \\
\hline Main bedrock distribution $(\%)$ & \\
\hline Granodiorite granite & 89 \\
Tonalite granodiorite & 6 \\
Dacite rhyolite & 3 \\
Granite & 2 \\
\hline
\end{tabular}

cultural catchments in Sweden (Linefur et al., 2018; Kyllmar et al., 2014). The dissolved oxygen (D.O.) conditions are mainly undersaturated (median D.O. $=53 \%$ ) during the growing season. The arable fields are to a large extent artificially drained with extensive tile drainage pipe systems connected to the stream network.
Table 2. Water chemistry at the outlet of the SBM catchment collected during June-November 2017 ( $n=8)$ (Osterman, 2018).

\begin{tabular}{lrrr}
\hline & Median & Mean & Min-max \\
\hline $\mathrm{pH}$ & 7.7 & 7.8 & $7.4-8.4$ \\
$\mathrm{EC}\left(\mu \mathrm{S} \mathrm{cm}^{-1}\right)$ & 1082 & 1273 & $791-1908$ \\
$\mathrm{NH}_{4}-\mathrm{N}\left(\mathrm{mg} \mathrm{L}^{-1}\right)$ & 0.10 & 0.08 & $0.01-0.1$ \\
$\mathrm{NO}_{3}-\mathrm{N}\left(\mathrm{mg} \mathrm{L}^{-1}\right)$ & 0.7 & 1.9 & $0.09-6.5$ \\
$\mathrm{PO}_{4}-\mathrm{P}\left(\mathrm{mg} \mathrm{L}^{-1}\right)$ & 0.07 & 0.09 & $0.01-0.2$ \\
DOC $\left(\mathrm{mg} \mathrm{L}^{-1}\right)$ & 10.0 & 9.6 & $4.2-13.1$ \\
D.O. $(\%)$ & 53 & 62 & $31-119$ \\
\hline
\end{tabular}

To explore how representative the SBM catchment is for streams draining agricultural areas in the region, a snapshot sampling survey was performed across 10 streams (denoted region UPP 2 in the study by Audet et al., 2020) of various sizes (catchment area $8.5-740 \mathrm{~km}^{2}$ ) and agricultural influences $(30 \%-86 \%)$ distributed within a radius of $10 \mathrm{~km}$ from the city centre of Uppsala (Fig. 1a, Table S1 in the Supplement).

\subsection{Field sampling and analysis}

The measurements were conducted from 26 September 2017 to 12 December 2018 (in total $339 \mathrm{~d}$ of measurements excluding periods of ice and snow cover). Stream $\mathrm{CO}_{2}$ concentration was monitored using an eosGP sensor (Eosense, Dartmouth, Canada). The sensor was covered by copper tape 
in order to avoid biofouling. Sensor accuracy is $<1 \%$ of the calibrated range $\left(0 \%-2 \% \mathrm{CO}_{2}\right)+1 \%$ of the reading, corresponding to a maximum error of ca. $0.3 \mathrm{mg} \mathrm{C} \mathrm{L}^{-1}$ based on the maximum $\mathrm{CO}_{2}$ measured in the current study. The $\mathrm{CO}_{2}$ sensor was calibrated against known gas standards $(400$, 1000,5000 , and $20000 \mathrm{ppm}$ ) before and after deployment. No significant drift (exceeding the above-given uncertainty) in the instrument was observed during the period. Volume fraction outputs from the sensor were corrected for variations in temperature and pressure (atmospheric and water depth) using the method described in Johnson et al. (2010) and expressed in milligrammes of carbon per litre.

Water level, water temperature, and EC were measured together with $\mathrm{CO}_{2}$ concentration at a $V$-notch weir (Fig. S1 in the Supplement). Water level was measured using a pressure transducer (1400, MJK Automation, Sweden) mounted in a stilling well representing the stream water level at the $V$ notch weir. Discharge was calculated from a stage-discharge rating curve based on a series of manual measurements and according to a rating curve presented in Holmqvist (1998). Water temperature and EC were monitored using a thermocouple (Type T) and a CS547A-L conductivity sensor (Campbell, UK), respectively. The sensors (except for the pressure transducer) were deployed under the water surface attached to a wooden rod in the centre of the stream just upstream of the weir. All sensors were connected to a CR1000X data logger (Campbell, UK) measuring at a 1 min interval and storing average values at a temporal resolution of 30 (in 2017) or $60 \mathrm{~min}$ (in 2018).

Stable isotopic analysis of the dissolved inorganic carbon (DIC) $\left(\delta^{13} \mathrm{C}\right.$-DIC) was performed on six occasions during the falling limb of the snowmelt discharge peak in 2018 in order to explore the temporal variability in DIC source. At each sampling occasion a sample for analysis of $\delta^{13} \mathrm{C}$-DIC was taken in a $60 \mathrm{~mL}$ glass vial completely filled with stream water and closed airtight with a rubber septum below the water surface. In order to preserve the sample, $1 \mathrm{~mL}$ of highly concentrated $\mathrm{ZnCl}_{2}$ solution was injected in each sample (with subsequent release of $1 \mathrm{~mL}$ of sample in order to keep atmospheric pressure) directly after sample collection. Samples were kept cold and dark until analysis. Prior to analysis, $2 \mathrm{~mL}$ of sample was injected into $12 \mathrm{~mL}$ septum-sealed pre-combusted glass vials (Labco Limited) pre-filled with $\mathrm{He}$ gas and pre-injected with $0.1 \mathrm{~mL}$ of concentrated phosphoric acid in order to convert all DIC species to $\mathrm{CO}_{2}(\mathrm{~g})$ (Campeau et al., 2017a). The samples were analysed using an isotope ratio mass spectrometer (DELTA V Plus, Thermo Fisher Scientific, Bremen, Germany) GasBench II (Thermo Fisher Scientific, Bremen, Germany) measuring the $\mathrm{CO}_{2}$ in the headspace. Each sample was analysed seven times (sample volume; $100 \mu \mathrm{L}$ per sample), and the first two injections for each sample were discarded to avoid memory effects. The mean of the other five samples was taken to give the final result. The $\delta^{13} \mathrm{C}$-DIC values are given in terms of deviation from known carbonate standards in per mille, where $R$ is the

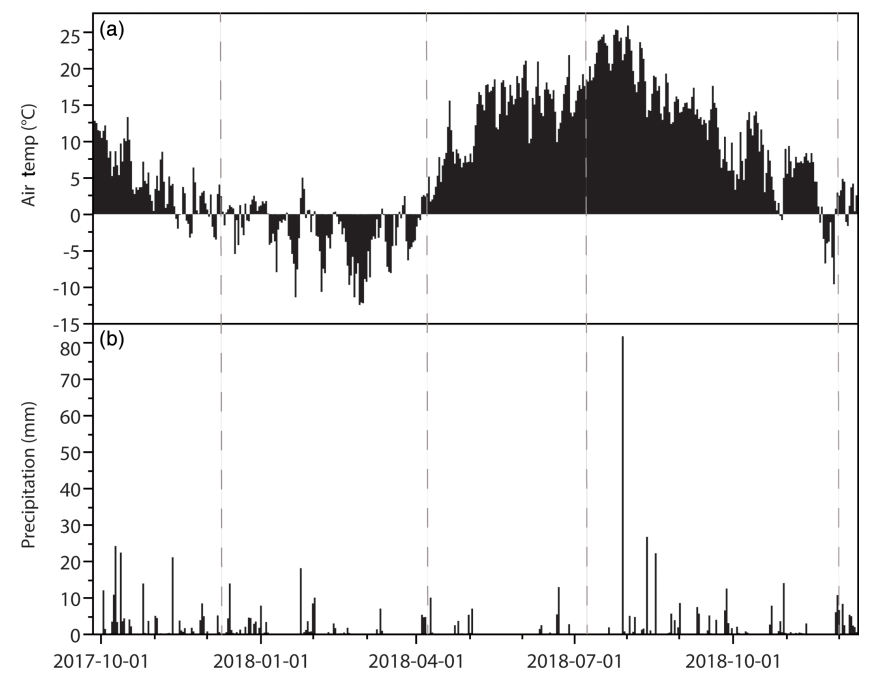

Figure 2. (a) Daily mean air temperature, and (b) daily precipitation during the study period (26 September 2017-12 December 2018) at the Marsta observatory. Due to malfunctioning sensor the precipitation data for 29 July 2018 is collected from the nearby ( $3 \mathrm{~km}$ ) SMHI station, Ärna. The dotted lines refer to the hydrological periods displayed in Fig. 3.

isotopic ratio of $\left[{ }^{13} \mathrm{C}\right] /\left[{ }^{12} \mathrm{C}\right]$ :

$\delta^{13} \mathrm{C}$-DIC $(\% \circ)=\left(R_{\text {sample }} / R_{\text {standard }}-1\right) \times 1000$.

Precipitation, air temperature, and incoming shortwave (global) radiation data (Fig. 2) were obtained from the Marsta meteorological observatory located within the catchment ca. $2.5 \mathrm{~km}$ from the stream sampling station (Halldin et al., 1999). In the absence of direct measurements of photosynthetically active radiation (PAR), shortwave incoming radiation was used as a proxy for available photosynthetic light.

A spatial sampling campaign for $\mathrm{CO}_{2}$ concentration, $\mathrm{pH}$, $\mathrm{EC}$, and water temperature was conducted on 21 June 2018 across 10 agricultural streams (including the SBM stream) located in different catchments around the city of Uppsala (Fig. 1a). The sampling was performed between 10.00 and 14.00 during the day. Samples for $\mathrm{CO}_{2}$ analysis were collected using the headspace method (Hope et al., 2004; Kokic et al., 2015). Briefly, $30 \mathrm{~mL}$ of bubble-free water was collected in $60 \mathrm{~mL}$ polypropylene syringes and equilibrated with a known volume of ambient air by shaking vigorously for $1 \mathrm{~min}$. The equilibrated headspace $(15-20 \mathrm{~mL})$ was recovered and analysed on an ultra-portable greenhouse gas analyser (UGGA) (Los Gatos Research, USA) equipped with a soda lime filter and manual injection port. In situ $\mathrm{CO}_{2}$ concentration was calculated from the UGGA-determined parts per million values using Henry's law considering stream temperature (Weiss, 1974), atmospheric pressure, the added ambient air, and the water-air volume ratio in the syringe. The $\mathrm{pH}, \mathrm{EC}$, and water temperature were measured in situ in the streams with handheld instruments, for $\mathrm{pH}$ with a $\mathrm{pH} 110 \mathrm{pH}$ 
meter (VWR, USA) and for EC and temperature with a HI 99300 (Hanna Instr., USA).

\subsection{Delineation of the stream network and catchment characteristics}

Catchment area and characteristics were calculated in QGIS 3.8 based on a high-resolution $(2 \mathrm{~m} \times 2 \mathrm{~m})$ digital elevation model (DEM) derived from lidar data (GSD elevation data, grid 2+, Swedish Land Survey). Land use distribution within the catchment was derived from the CORINE Land Cover 2018 product (European Environment Agency), and soil and bedrock characteristics were based on digital versions of the Quaternary deposits (1:25000-1 : 100000) and bedrock (1: 50000-1: 250000) maps (Swedish Geological Survey).

\subsection{Data analysis}

Out of the total data set ( $339 \mathrm{~d})$ from the SBM catchment, only data measured at discharge rates $>0 \mathrm{Ls}^{-1}$ (i.e excluding standing water or completely dry conditions) were used in the analysis of the stream $\mathrm{CO}_{2}$ data (Fig. S1). For further evaluation of the control on stream $\mathrm{CO}_{2}$ concentration, the data set was divided into four periods (autumn, $49 \mathrm{~d}$; snowmelt, $17 \mathrm{~d}$; spring, $91 \mathrm{~d}$; and the dry period, $138 \mathrm{~d}$ ) according to distinct phases in the hydrograph (Fig. 3, Table S2). The stream $\mathrm{CO}_{2}$ dynamics observed among the different periods were examined visually, and any hydrological controls on the $\mathrm{CO}_{2}$ were identified by the presence and direction of $\mathrm{CO}_{2}$-discharge hysteresis loops (Evans and Davies, 1998). Similar hysteresis analysis was used to investigate diel patterns in the $\mathrm{CO}_{2}$ concentration data. Spearman's rank correlation coefficient was used to test for monotonic relationships between the diel amplitude in stream $\mathrm{CO}_{2}$ concentration and potential drivers. Correlations were considered significant if $p<0.05$. The software JMP 14.2.0 (SAS Institute Inc., Cary, NC, USA) was used for all statistical calculations.

\section{Results}

The mean air temperature and total precipitation for the entire period (26 September 2017-12 December 2018) were $6.8^{\circ} \mathrm{C}$ and $704 \mathrm{~mm}$, respectively. The summer and autumn of 2018 were dry with generally low precipitation; the exception was on July 29 with $82 \mathrm{~mm}$ of rain within 24 h (Fig. 2). Mean and median stream discharge for the study period were 30.6 and $0.9 \mathrm{~L} \mathrm{~s}^{-1}$, respectively, and with a total range from 0 to $668 \mathrm{~L} \mathrm{~s}^{-1}$ (corresponding to a range from 0 to $5.0 \mathrm{~mm} \mathrm{~d}^{-1}$ ) (Fig. 3). However, due to a high water table exceeding the range of the pressure transducer, the absolute peak discharge occurring from 5 to 7 April was missed in the measurements. The large skewness between mean and median discharge was an effect of the large number of days without water flow over

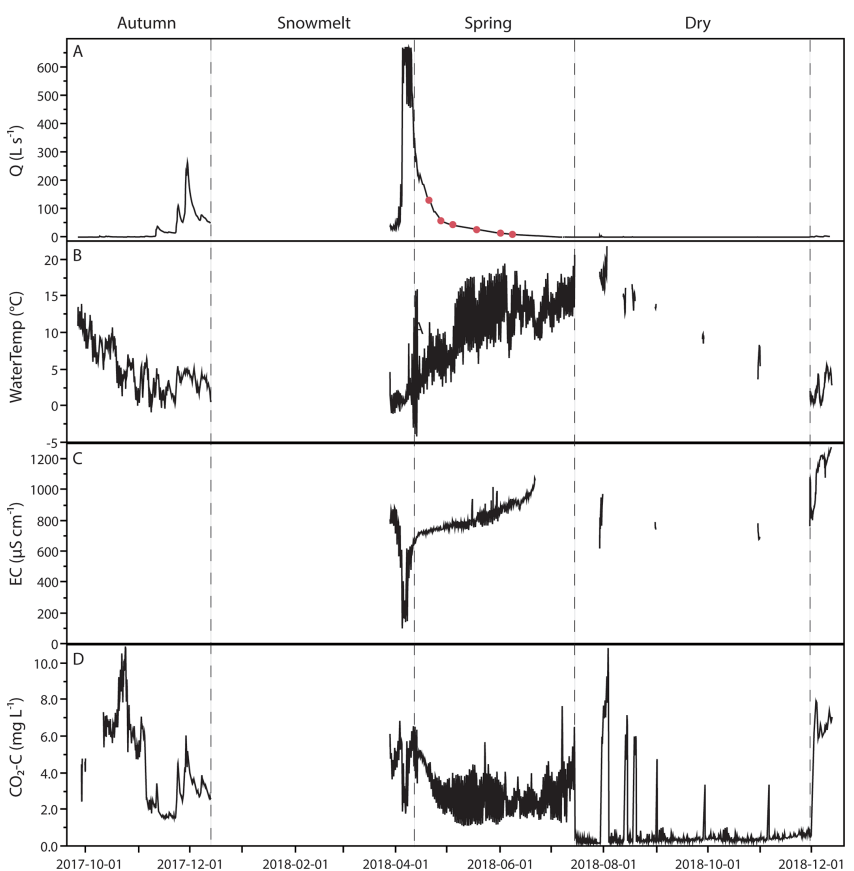

Figure 3. Time series of (a) stream discharge $(Q)$ with sampling days for $\delta^{13} \mathrm{C}$-DIC highlighted by red dots, (b) stream water temperature, (c) electrical conductivity (EC), and (d) $\mathrm{CO}_{2}$ concentration for the study period 26 September 2017-12 December 2018, with a break for the ice- and snow-covered period DecemberMarch. The $\mathrm{CO}_{2}$ data include periods when the sensor was above the water surface during dry periods in summer and autumn of 2018.

the weir during summer and autumn 2018, $128 \mathrm{~d}(38 \%)$ out of the study period. According to frequency analysis, $67 \%$ of the days had a mean daily discharge $<5 \mathrm{~L} \mathrm{~s}^{-1}$. Despite the few days with discharge $>100 \mathrm{Ls}^{-1}$ (7\% of the entire period), those days accounted for $69 \%$ of the accumulated discharge. The majority ( $84 \%$ ) of these high-discharge days occurred during the snowmelt in April.

\subsection{General $\mathrm{CO}_{2}$ patterns}

The stream $\mathrm{CO}_{2}$ concentrations during the entire study period (median and mean of 3.44 and $3.94 \mathrm{mg} \mathrm{CL}^{-1}$, respectively, corresponding to a $p \mathrm{CO}_{2}$ of 4778 and $\left.5324 \mu \mathrm{atm}\right)$ were highly variable $\left(\mathrm{IQR}=3.26 \mathrm{mg} \mathrm{C} \mathrm{L}^{-1}\right)$ (Fig. 3) and displayed a bimodal distribution with frequency peaks at $\sim 2.7$ and $\sim 6.1 \mathrm{mg} \mathrm{CL}^{-1}$ (Fig. S2). The lower peak was associated with the snowmelt and spring period, whereas the higher peak was attributed to the autumn period in 2017 and to rain events during the dry period of summer-autumn 2018. In addition to the bimodal shape, a very distinct peak in frequently measured concentrations was observed at $\sim 1.6 \mathrm{mg} \mathrm{CL}^{-1}$. This peak was attributed to the minimum concentration values for the diel cycles observed during the spring period. 

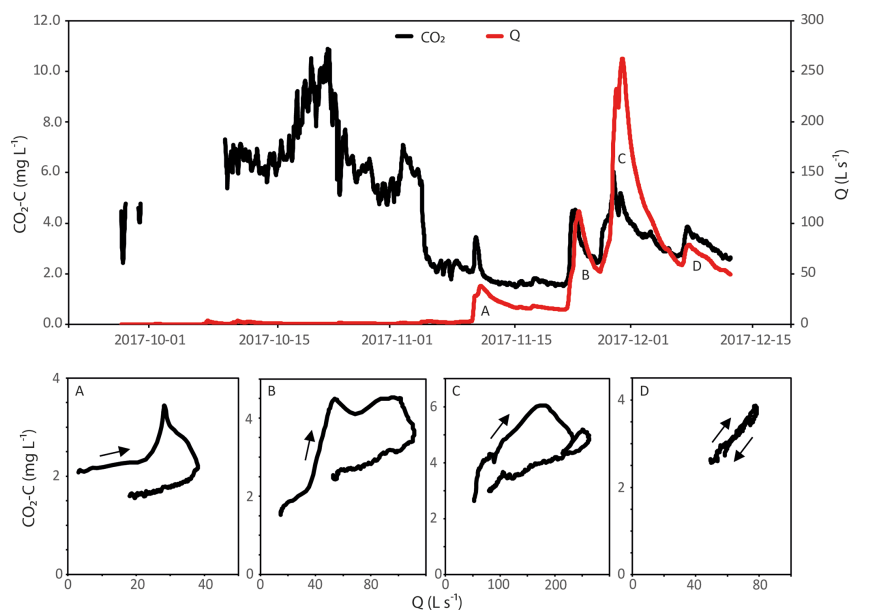

Figure 4. Stream $\mathrm{CO}_{2}$ concentration (black) and discharge (red) for the autumn 2017 period with $\mathrm{CO}_{2}-Q$ hysteresis plots for four rain events.
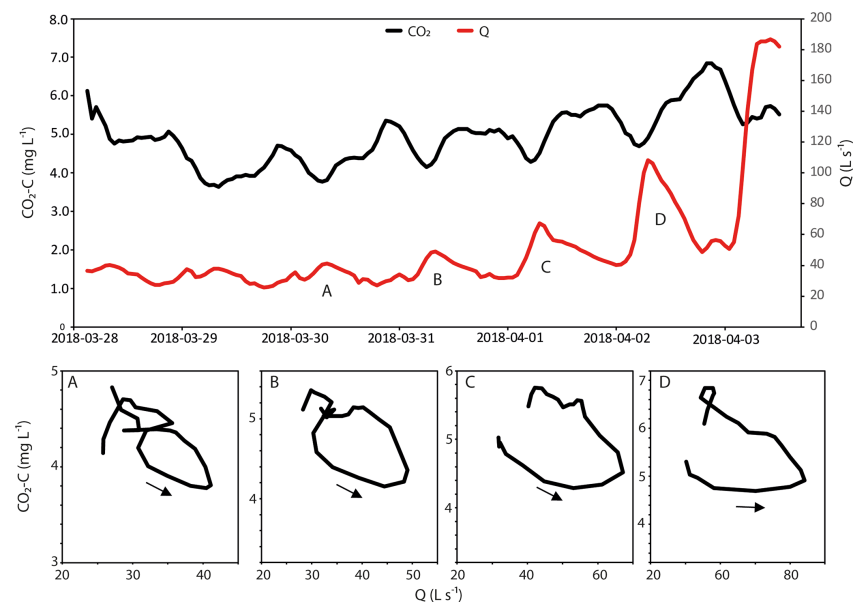

Figure 5. Stream $\mathrm{CO}_{2}$ concentration (black) and discharge (red) for the snowmelt period 2018 with $\mathrm{CO}_{2}-Q$ hysteresis plots for four discharge events.

\subsection{Controls on stream $\mathrm{CO}_{2}$ concentration}

The autumn period started dry with low discharge $\left(<3 \mathrm{~L} \mathrm{~s}^{-1}\right)$ for the initial month of measurements. The $\mathrm{CO}_{2}$ concentrations were at the same time highly dynamic but unrelated to variations in discharge. The $\mathrm{CO}_{2}$ concentration reached the maximum for the autumn $\left(10.89 \mathrm{mg} \mathrm{CL}^{-1}\right.$, which was also the maximum for the entire study period) during late October followed by a decline in $\mathrm{CO}_{2}$ to ca. $2 \mathrm{mg} \mathrm{CL}^{-1}$ in early November. During November and December four main rain events were identified which all displayed an increasing stream $\mathrm{CO}_{2}$ concentration with increasing discharge. In three of these events a positive clock-wise hysteresis loop was observed (Fig. 4) where the $\mathrm{CO}_{2}$ concentration reached its maximum before the discharge did. At the last event during autumn 2017, the relationship between $\mathrm{CO}_{2}$ concentra-
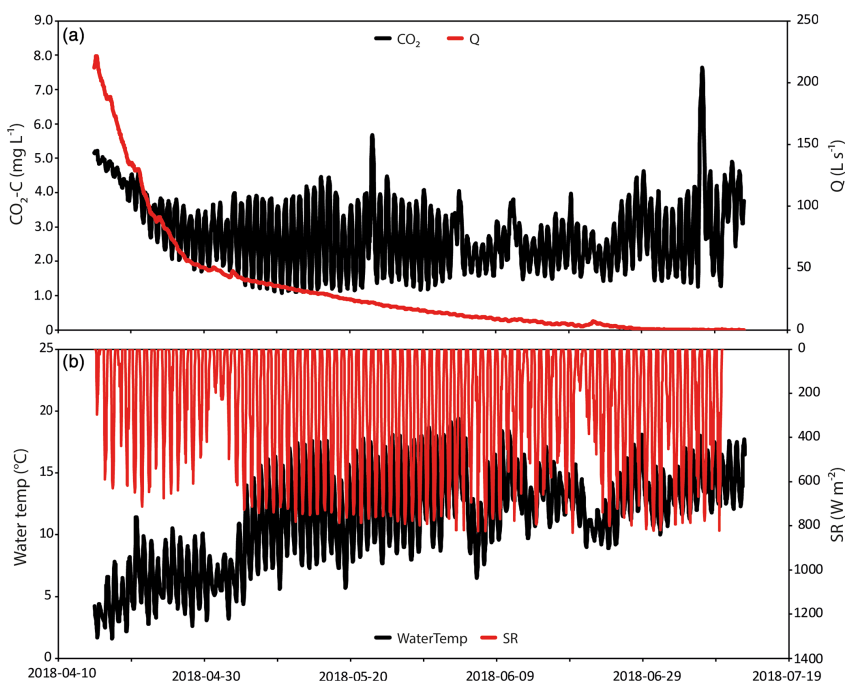

Figure 6. Time series of (a) stream $\mathrm{CO}_{2}$ concentration (black) and discharge (red) and (b) water temperature (black) and shortwave incoming radiation (SR, red) covering the period April-July 2018. Note the reverse axis for shortwave incoming radiation.

tion and discharge was close to linear, but still positive. During the snowmelt period the hydrograph was characterized by a diel cycle with melting during daytime, resulting in daily discharge peaks which were suppressed during night-time freezing. In contrast to the autumn events, the daily discharge peaks were negatively related to the stream $\mathrm{CO}_{2}$ concentration and with an anticlockwise hysteresis loop where the minimum $\mathrm{CO}_{2}$ concentration was reached before the highest discharge of the event (Fig. 5). After the snowmelt discharge peak, the spring and early summer periods (late April to early July) were dry with limited precipitation and with a steady decline in runoff (Fig. 3). During this period the $\mathrm{CO}_{2}$ concentration displayed a pronounced diel cycle with daily maximum and minimum $\mathrm{CO}_{2}$ concentrations reached during early mornings (06:00) and late afternoons (18:00), respectively (Fig. 6). The medium amplitude of the diel $\mathrm{CO}_{2}$ cycle for this period was $2.03 \mathrm{mg} \mathrm{CL}^{-1}$, corresponding to $p \mathrm{CO}_{2}=2974 \mu \mathrm{atm}\left(\mathrm{IQR}=1.23 \mathrm{mg} \mathrm{CL}^{-1}\right.$, corresponding to $p \mathrm{CO}_{2}=2212 \mu \mathrm{atm}$ ), and with the size of the diel $\mathrm{CO}_{2}$ concentration amplitude being related to both the daily mean water temperature and the shortwave radiation (Fig. 7). The diel pattern displayed a clear negative anti-clockwise $\mathrm{CO}_{2-}$ stream water temperature hysteresis loop, where the median $\mathrm{CO}_{2}$ concentration could differ by up to $75 \%$ between daytime and night-time despite being measured at the same stream water temperature (Fig. 8).

From early July the stream dried out and hence no runoff over the $V$-notch weir was generated. During this period the $\mathrm{CO}_{2}$ sensor mostly recorded an atmospheric signal. However, for five rain events during the summer and early autumn, runoff was generated, which allowed stream $\mathrm{CO}_{2}$ determination for shorter periods (Fig. 9). During these 


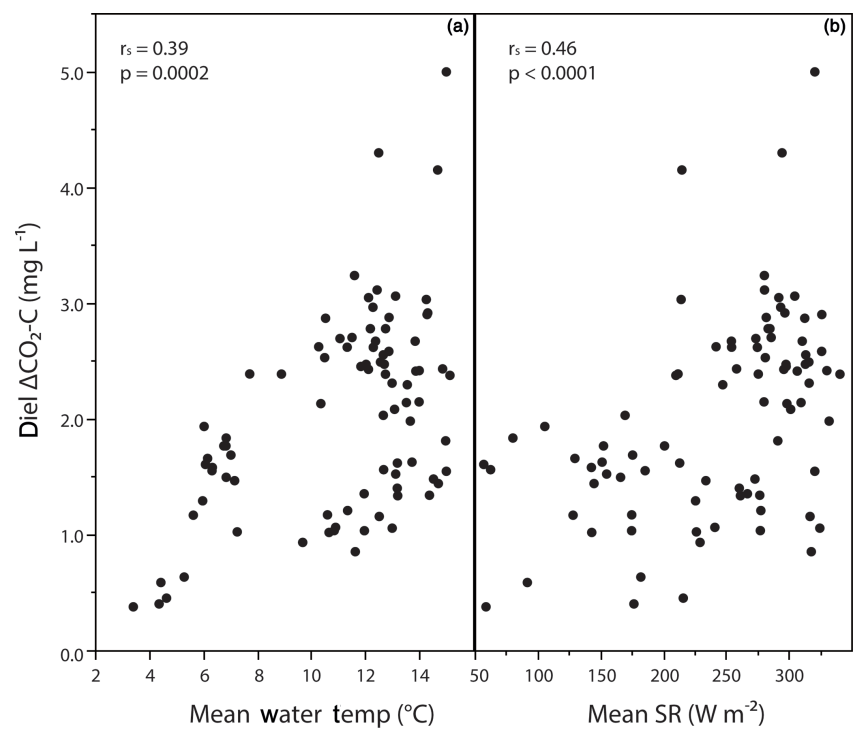

Figure 7. Diel amplitude in stream $\mathrm{CO}_{2}$ concentration in relation to (a) daily mean stream water temperature and (b) daily mean shortwave radiation (SR), covering the period April-July 2018. Statistics are given according to Spearman's rank correlation.

runoff events $\left(<2 \mathrm{~d}\right.$ long), high $\mathrm{CO}_{2}$ concentration pulses were recorded (up to $11 \mathrm{mg} \mathrm{CL}^{-1}$ ). At all events $\mathrm{CO}_{2}$ was recorded for a longer period than the discharge as the small dam above the $V$-notch weir was still water-filled for some time after runoff over the weir ceased. Also, common for all events was that the stream $\mathrm{CO}_{2}$ concentration continued to increase although the discharge peak had passed. During 29 July a heavy rainstorm occurred with $82 \mathrm{~mm}$ of precipitation in $24 \mathrm{~h}$. Although more than $15 \%$ of the long-term annual mean precipitation fell during $1 \mathrm{~d}$, low discharge was generated (maximum discharge $6.1 \mathrm{~L} \mathrm{~s}^{-1}$ ) due to high evapotranspiration and dry soils (Figs. 3 and 9). However, the rainstorm event resulted in close to the highest stream $\mathrm{CO}_{2}$ concentration (10.81 $\mathrm{mg} \mathrm{C} \mathrm{L}^{-1}$ ) being observed during the studied period. As soon as the stream was more permanently refilled in early December and with discharge generated over the weir, the stream $\mathrm{CO}_{2}$ concentration was back to similarly high levels (typically $5-8 \mathrm{mg} \mathrm{CL}^{-1}$ ) as observed in the autumn of 2017.

\subsection{Sources of DIC}

The $\delta^{13} \mathrm{C}$-DIC data collected during the falling limb of the spring discharge peak (discharge range $130-9.6 \mathrm{~L} \mathrm{~s}^{-1}$ ) ranged from $-13.8 \%$ to $-12.2 \%$. This narrow range suggests a relatively constant source of inorganic $\mathrm{C}$ during the spring period. Although there was a tendency towards more negative $\delta^{13} \mathrm{C}$-DIC values at higher discharge, no significant relationship was found (Fig. 10). $\delta^{13} \mathrm{C}$-DIC was also unrelated to the stream $\mathrm{CO}_{2}$ concentration (data not shown).

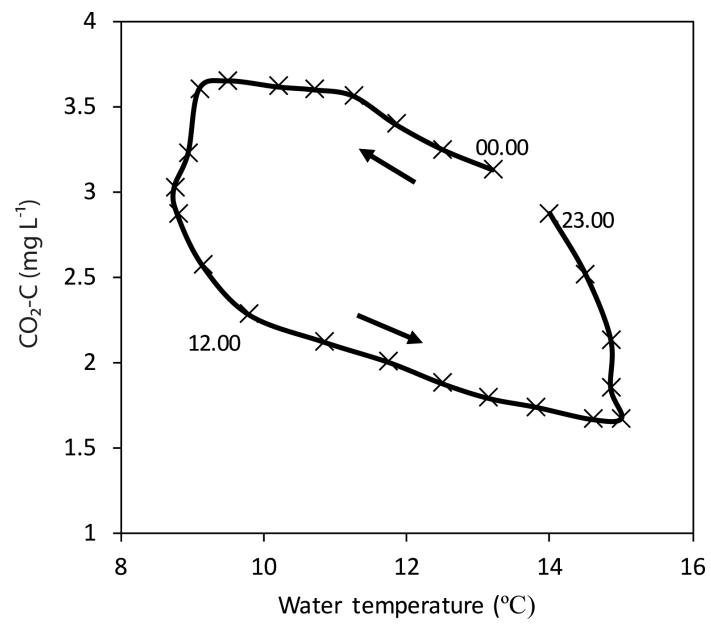

Figure 8. $\mathrm{CO}_{2}$-water temperature hysteresis loop based on the median daily values presented in Fig. 7 covering the period AprilJuly 2018.

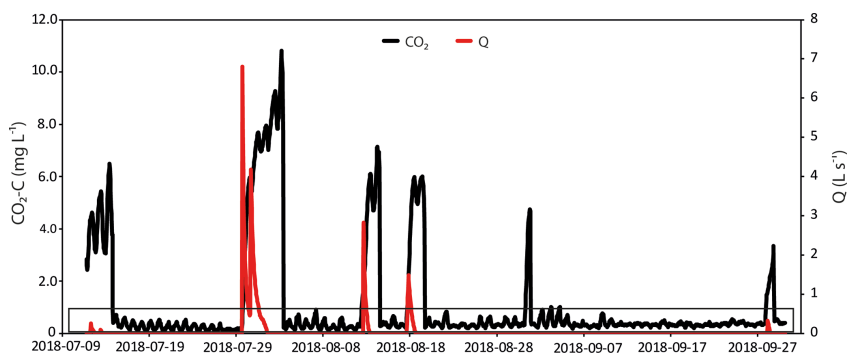

Figure 9. Stream $\mathrm{CO}_{2}$ concentration (black) and discharge (red) for the dry period (July-September 2018). Periods when the $\mathrm{CO}_{2}$ sensor was above the water table capturing an atmospheric signal (i.e. with concentrations $<0.5 \mathrm{mg} \mathrm{C} \mathrm{L}^{-1}$ ) are highlighted by the lower box.

\subsection{Spatial representativeness}

The 10 streams manually sampled around Uppsala displayed a wide range in $\mathrm{CO}_{2}$ concentrations $\left(1.8-4.6 \mathrm{mg} \mathrm{CL}^{-1}\right)$ on the day of sampling (21 June 2018) and with the SBM stream (site 3 in Table S1) being close to the overall median (SBM, $2.7 \mathrm{mgCL}^{-1}$; overall median, $3.0 \mathrm{mg} \mathrm{CL}^{-1}$ ) (Table S1). Furthermore, the $\mathrm{CO}_{2}$ concentration manually sampled at $\mathrm{SBM}$ was close to the sensor-recorded $\mathrm{CO}_{2}\left(2.59 \mathrm{mg} \mathrm{C} \mathrm{L}^{-1}\right)$ at the hour of sampling. The SBM stream was also close to the spatial median DOC concentration but slightly elevated in $\mathrm{NO}_{3}$ and $\mathrm{PO}_{4}$. The $\mathrm{CO}_{2}$ concentration was on a spatial scale related to $\mathrm{pH}$ but unrelated to catchment area or land use distribution within the catchment. Furthermore, the $\mathrm{CO}_{2}$ concentration was on a spatial scale unrelated to mean stream concentrations of DOC, $\mathrm{PO}_{4}$, and $\mathrm{NO}_{3}$, although these variables were sampled during a different period than the $\mathrm{CO}_{2}$. 


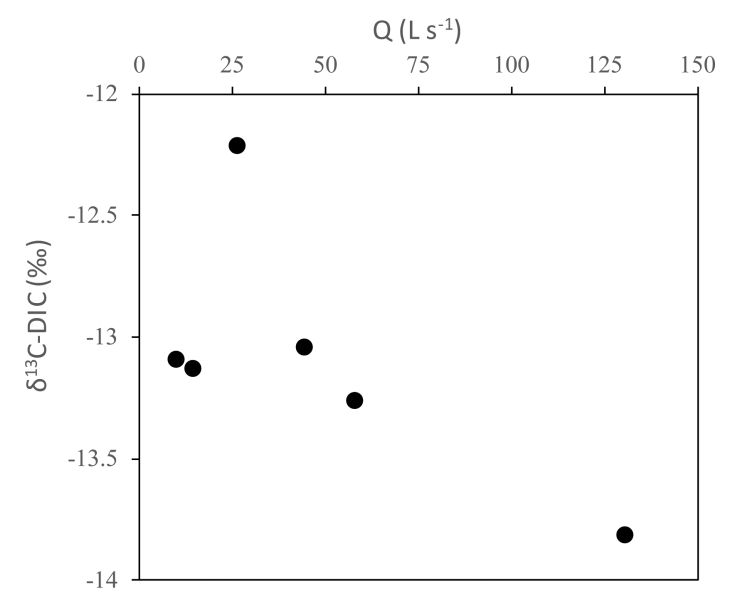

Figure 10. $\delta^{13} \mathrm{C}$-DIC as a function of stream discharge. The six sampling occasions covered the falling limb of the snowmelt peak in April-June 2018.

\section{Discussion}

In order to produce large-scale estimates of the exchange of greenhouse gases (GHGs) between inland surface waters and the atmosphere, a basic requirement is to know the aqueous concentrations of the gases of interest and how they might vary over time. Headwater streams have been identified as "hotspots" for $\mathrm{CO}_{2}$ emissions (Raymond et al., 2013; Wallin et al., 2018), but there are limited data capturing the temporal resolution, specifically from streams draining agricultural regions, making large-scale generalizations uncertain. Due to effective drainage, high-nutrient conditions and often high sunlight exposure (due to limited tree cover), agricultural streams could potentially be very different in their $\mathrm{CO}_{2}$ dynamics compared with streams draining other environments. Here we continuously measured stream $\mathrm{CO}_{2}$ concentration in a headwater catchment dominated by agricultural land use ( $86 \%$ ) covering more than 1 year of the snowfree period. In line with findings from similar studies from other environments (arctic tundra, boreal forest, temperate peatlands, alpine areas) (e.g. Rocher-Ros et al., 2019; Riml et al., 2019; Crawford et al., 2017; Peter et al., 2014; Dinsmore et al., 2013), we found a mixture of controls on stream $\mathrm{CO}_{2}$ operating at different timescales, generating a highly dynamic stream $\mathrm{CO}_{2}$ concentration pattern. These timescales cover seasonal patterns to diel cycles, or even shorter scales associated with discharge events. Both the magnitude of $\mathrm{CO}_{2}$ concentrations and their associated temporal dynamics were found to be high in the current agricultural stream when compared with the literature. The mean $\mathrm{CO}_{2}$ concentration ( $3.94 \mathrm{mg} \mathrm{C} \mathrm{L}^{-1}$ corresponding to a $p \mathrm{CO}_{2}$ of $5324 \mu \mathrm{atm}$ ) is at the high end when compared with other high-frequency $\mathrm{CO}_{2}$ data sets covering low-order (less than third stream order) catchments draining multiple environments, including arctic tundra, boreal forest, hemi-boreal forest, temperate forest, temperate peatlands, and alpine areas (typically ranging from ca. 0.2 to $6 \mathrm{mg} \mathrm{C} \mathrm{L}^{-1}$ ) (Crawford et al., 2017; Natchimuthu et al., 2017; Peter et al., 2014; Dinsmore et al., 2013). Still, $\mathrm{CO}_{2}$ concentrations in SBM do not seem to be exceptionally high compared to snapshot-based data from other agricultural streams.

The spatial variability seen in this study, although only based on snapshot samples, and previous studies indicates that $\mathrm{CO}_{2}$ concentrations in agricultural streams are comparably high (Borges et al., 2018; Bodmer et al., 2016; SandJensen and Staehr, 2012). In addition, the observed temporal dynamics presented here are, to our knowledge, among the most pronounced in the literature, although the number of high-frequency stream $\mathrm{CO}_{2}$ data sets is limited, for example, the rapid decrease in stream $\mathrm{CO}_{2}$ during the autumn of 2017, the strong diel cycle (diel amplitude up to almost $5.0 \mathrm{mg} \mathrm{C} \mathrm{L}^{-1}$ ) during the spring-early summer period, or the rapid and high $\mathrm{CO}_{2}$ pulses (up to $11.0 \mathrm{mg} \mathrm{C} \mathrm{L}^{-1}$ ) occurring in accordance with rain events during the dry late summerautumn period. These high $\mathrm{CO}_{2}$ dynamics clearly illustrate the need for continuous high-frequency $\mathrm{CO}_{2}$ concentration measurements in streams in general, and in agricultural streams more specifically. Without such high-frequency data, representative estimates of agricultural stream $\mathrm{CO}_{2}$ will be associated with high uncertainty. Although based on measurements from a single stream, these findings in turn indicate that current large-scale stream $\mathrm{CO}_{2}$ emission estimates (e.g. Raymond et al., 2013; Humborg et al., 2010), which are largely based on snapshot concentration data with low (or no) resolution in time, might be specifically uncertain for agricultural regions.

According to our continuous data the highly dynamic pattern in stream $\mathrm{CO}_{2}$ concentration is driven by a complex interplay of hydrology and biology. The high autumn concentrations observed in both 2017 and 2018 are likely an effect of high respiration of organic matter in the stream channel and/or in the adjacent soil water (Fig. 3d). This is supported by efficient aquatic microbial DOC degradation $\left(<800 \mu \mathrm{g} \mathrm{CL}^{-1} \mathrm{~d}^{-1}\right)$ observed during the autumn period across the 10 streams (agricultural land use, 30\%$86 \%$ ) included in the spatial sampling campaign (Peacock et al., unpublished data). This could be compared with organic $\mathrm{C}$ degradation rates determined in boreal forest and mire streams displaying typically lower rates $\left(<300 \mu \mathrm{g} \mathrm{CL}^{-1} \mathrm{~d}^{-1}\right.$; Berggren et al., 2009). The positive $\mathrm{CO}_{2}$-discharge relationships indicated that event flow pathways were in contact with soils with higher concentrations of $\mathrm{CO}_{2}$ compared to flow pathways during base flow (Evans and Davies, 1998; Seibert et al., 2009). Also, the clockwise shape of the hysteresis loop suggests that there is a buildup of $\mathrm{CO}_{2}$ in the catchment that is flushed out during rain events (Fig. 4). The $\mathrm{CO}_{2}$ pool seems to be limited as the $\mathrm{CO}_{2}$ concentration drops before the maximum discharge peak occurs, and vertical patterns in the $\mathrm{CO}_{2}$ soil profile control the stream $\mathrm{CO}_{2}$ depending on dominating flow paths (Evans and 
Davies, 1998; Öquist et al., 2009). This could explain the fact that the stream $\mathrm{CO}_{2}$ increase did not reach any source limitation for rain events of lower magnitude (Fig. 4d). Similar positive $\mathrm{CO}_{2}$ concentration-discharge patterns have been observed across different low-order streams (e.g. Crawford et al., 2017; Dinsmore et al., 2013), but the absolute patterns are often concluded to be highly site-specific and even event-specific. Here we suggest, by exploring the hysteresis loops, that such positive relationships are influenced by the size of the available catchment $\mathrm{CO}_{2}$ pool or the hydrological connectivity to it. In a highly drained low-elevation agricultural landscape where much of the stream runoff is generated through drainage pipes (Castellano et al., 2019), the extent and spatial distribution of these terrestrial source areas and connections between groundwater and surface water are central for the $\mathrm{CO}_{2}$ patterns observed in the stream. Strong hydrological control has been found for DOC in agricultural streams in the USA and France, where high-discharge events flush allochthonous DOC, via subsurface drainage pipes, into streams (Morel et al., 2009; Royer and David, 2005). In contrast to the seasonally variable $\mathrm{CO}_{2}$-discharge response patterns observed in the current study, Morel et al. (2009) suggested that stream DOC is non-limited and would continue to rise until the maximum discharge peak is reached. Whether this discrepancy in source limitation between $\mathrm{CO}_{2}$ and DOC (although based on different studies and environments) indicates differences in the source areas of the different carbon components requires further investigation.

In contrast to the patterns observed during the autumn, during the snowmelt period the stream $\mathrm{CO}_{2}$ was diluted when discharge increased following a diel pattern (Fig. 5). The melting and freezing between daytime and night-time suggest that meltwater from the surface snowpack during daytime to a larger extent reached the stream without picking up an elevated $\mathrm{CO}_{2}$ signal. Similar dilution patterns in conjunction with snowmelt have been observed in catchments of various land use but specifically in peatland catchments with limited forest cover (e.g. Wallin et al., 2013). The similarity between this agricultural catchment and open peatlands could potentially be the effect of an efficient melting of the snowpack. Both unforested peatlands and agricultural fields are open areas subject to direct sunlight and wind and rain exposure, while the soil under the snow remains frozen. As a result, a large share of the meltwater will never infiltrate the soil but instead reaches the surface drainage system as overland flow (Laudon et al., 2007). This is further accompanied by the low hydraulic conductivity of clay soils, which dominate the catchment of the current study. Although we did not capture the $2-3 \mathrm{~d}$ of peak spring flood (due to a water level out of the range of the pressure transducer), it was evident that the stream $\mathrm{CO}_{2}$ concentration was diluted from ca. 6.0 to ca. $2.0 \mathrm{mg} \mathrm{C} \mathrm{L}^{-1}$ during these days, something that is further supported by the similar drop in EC during the peak spring flood from ca. 900 to ca. $150 \mu \mathrm{S} \mathrm{cm}^{-1}$. However, as soon as the discharge peak passed, the stream $\mathrm{CO}_{2}$ concen- tration recovered rapidly to the pre-peak levels, suggesting a shift to hydrological pathways that mobilize a high $\mathrm{CO}_{2}$ pool, again supported by the concurrent increase in EC. April and May 2018 were characterized by warm and clear weather with an average $4.2^{\circ} \mathrm{C}$ higher air temperature and 255 more sun hours than the 30-year mean (1961-1990, SMHI). Altogether, this stimulates a kick-start of the aquatic primary production upon snowmelt, which likely explains the steady decline in $\mathrm{CO}_{2}$ that occurred during late April-early May. During the spring and early summer, a strong diel pattern in $\mathrm{CO}_{2}$ concentration further developed, likely driven by aquatic primary production consuming $\mathrm{CO}_{2}$ during daytime. Such diel $\mathrm{CO}_{2}$ patterns are commonly observed in stream $\mathrm{CO}_{2}$ time series at base flow or during receding flow conditions (e.g. Riml et al., 2019; Peter et al., 2014) and are especially pronounced in amplitude in nutrient-rich streams or in streams without canopy shading (Alberts et al., 2017; Crawford et al., 2017; Rocher-Ros et al., 2019). Initial evaluation of the $\delta^{13}$ C-DIC data collected during the spring period suggests a relatively steady mixture of geogenic and biogenic DIC although somehow related to variations in discharge (Fig. 10). However, given the suppressed stream $\mathrm{CO}_{2}$ during the spring period, together with the strong diel cycle caused by aquatic primary production, fractionation of a strict biogenic DIC pool (with a $\delta^{13} \mathrm{C}$-DIC from $-28 \%$ o to $-20 \%$ o) could theoretically push the $\delta^{13} \mathrm{C}$-DIC towards the less negative values observed in the current study (from $-13.8 \%$ o to $-12.2 \%$ ) (Campeau et al., 2017b). Combined studies on aquatic metabolism, C dynamics, and stable isotopic composition is recommended to disentangle the dynamic $\mathrm{CO}_{2}$ source patterns in this type of agricultural system.

The spring and early summer of 2018 were generally dry, leading to the stream channel drying out during long periods. The rapid rewetting periods $(<2 \mathrm{~d})$ that occurred following larger precipitation events resulted in high $\mathrm{CO}_{2}$ pulses (3$11 \mathrm{mg} \mathrm{C} \mathrm{L}^{-1}$ ), generally exceeding the overall median level of stream $\mathrm{CO}_{2}\left(3.44 \mathrm{mg} \mathrm{CL}^{-1}\right)$ observed during the study period. The intermittent nature of streams, with distinct drying and rewetting episodes, is known to generate high $\mathrm{CO}_{2}$ concentration pulses and subsequent emissions (Marcé et al., 2019). Such rapid pulses are generally suggested to be a result of intense respiration in the stream bed sediments upon rewetting, or due to a rapid mobilization of terrestrial $\mathrm{C}$, both organic (DOC) and inorganic $\left(\mathrm{CO}_{2}\right)$ in connection to precipitation events. However, the high $\mathrm{CO}_{2}$ pulses upon rewetting have mostly been found in areas that display pronounced dry and wet seasons, e.g. Mediterranean areas or Australia (e.g. Gómez-Gener et al., 2015; Looman et al., 2017). Here we show that such stream intermittency can also cause high and rapid $\mathrm{CO}_{2}$ pulses in a Swedish agricultural setting, highlighting the need for expanding the geographical coverage of studies that investigate stream intermittency in relation to GHG dynamics and emissions. Areas that display stream intermittency will likely also increase in the future given the predicted changes in temperature and precipitation patterns. 
An obvious tool in this work is the use of continuous sensorbased measurements which allows the capture of the episodic and unpredictable nature of these phenomena.

\section{Conclusions}

It is evident from the current study that the stream $\mathrm{CO}_{2}$ dynamics in an agricultural headwater catchment are highly variable across a variety of different timescales and with an interplay of hydrological and biological controls. The hydrological control was strong (although with both positive and negative influences dependent on season) and rapid in response to rainfall and snowmelt events. However, during growing-season base flow and receding flow conditions, the aquatic primary production seems to control the stream $\mathrm{CO}_{2}$ dynamics, which in turn sets the basis for atmospheric emissions. During the dry summer period, rapid rewetting following precipitation events generated high $\mathrm{CO}_{2}$ pulses exceeding the overall median level of stream $\mathrm{CO}_{2}$ (up to $3 \times$ higher). This finding thus highlights the importance of stream intermittency in agricultural areas and its effect on stream $\mathrm{CO}_{2}$ dynamics. Given the observed high levels of $\mathrm{CO}_{2}$ and its temporally variable nature, agricultural streams clearly need more attention in order to understand and incorporate these considerable dynamics in large-scale extrapolations.

Data availability. Data are available from the Uppsala University data repository at http://urn.kb.se/resolve?urn=urn:nbn:se:uu: diva-408793 (Wallin, 2020).

Supplement. The supplement related to this article is available online at: https://doi.org/10.5194/bg-17-2487-2020-supplement.

Author contributions. MBW and MW conceived the idea and designed the study. MBW funded and instrumented the catchment and analysed the data. MW conducted the GIS analysis. JA, MP, and ES provided ideas and data. MBW wrote the manuscript with great support from all co-authors.

Competing interests. The authors declare that they have no conflict of interest.

Acknowledgements. We thank Jacob Smeds, My Osterman, Philip Johansson, and Maud Oger for invaluable support in the field and lab.
Financial support. This research has been supported by funding to Marcus B. Wallin from the King Carl-Gustaf XVI award for environmental science, the Finn Malmgren foundation and Carl Tryggers foundation (grant no. 17:484). Joachim Audet was supported by FORMAS (grant no. 2015-1559).

Review statement. This paper was edited by Paul Stoy and reviewed by two anonymous referees.

\section{References}

Alberts, J. M., Beaulieu, J. J., and Buffam, I.: Watershed land use and seasonal variation constrain the influence of riparian canopy cover on stream ecosystem metabolism, Ecosystems, 20, 553567, https://doi.org/10.1007/s10021-016-0040-9, 2017.

Audet, J., Bastviken, D., Bundschuh, M., Buffam, I., Feckler, A., Klemedtsson, L., Laudon, H., Löfgren, S., Natchimuthu, S., Öquist, M., Peacock, M., and Wallin, M. B.: Forest streams are important sources for nitrous oxide emissions, Glob. Change Biol., 26, 629-641, https://doi.org/10.1111/gcb.14812, 2020.

Bastviken, D., Sundgren, I., Natchimuthu, S., Reyier, H., and Gålfalk, M.: Technical Note: Cost-efficient approaches to measure carbon dioxide $\left(\mathrm{CO}_{2}\right)$ fluxes and concentrations in terrestrial and aquatic environments using mini loggers, Biogeosciences, 12, 3849-3859. https://doi.org/10.5194/bg-12-3849-2015, 2015.

Berggren, M., Laudon, H., and Jansson, M.: Hydrological control of organic carbon support for bacterial growth in boreal headwater streams, Microb. Ecol., 57, 170-178, https://doi.org/10.1007/s00248-008-9423-6, 2009.

Bodmer, P., Heinz, M., Pusch, M., Singer, G., and Premke, K.: Carbon dynamics and their link to dissolved organic matter quality across contrasting stream ecosystems, Sci. Total Environ., 553, 574-586, https://doi.org/10.1016/j.scitotenv.2016.02.095, 2016.

Borges, A. V., Darchambeau, F., Lambert, T., Bouillon, S., Morana, C., Brouyère, S., Hakoun, V., Jurado, A., Tseng, H.C., Descy, J.-P., and Roland, F. A. E.: Effects of agricultural land use on fluvial carbon dioxide, methane and nitrous oxide concentrations in a large European river, the Meuse (Belgium), Sci. Total Environ., 610/611, 342-355, https://doi.org/10.1016/j.scitotenv.2017.08.047, 2018.

Campeau, A., Bishop K., Billett, M. F., Garnett, M. H., Laudon, H., Leach, J. A., Nilsson, M. B., Öquist, M. G., and Wallin, M. B.: Aquatic export of young dissolved and gaseous carbon from a pristine boreal fen: implications for peat carbon stock stability, Glob. Change Biol., 23, 5523-5536, https://doi.org/10.1111/gcb.13815, 2017a.

Campeau, A., Wallin, M. B., Giesler, R., Löfgren, S., Mörth, CM., Schiff, S. L., Venkiteswaran, J. J., and Bishop, K.: Multiple sources and sinks of dissolved inorganic carbon across Swedish streams, refocusing the lens of stable C isotopes, Sci. Rep., 7, 9158, https://doi.org/10.1038/s41598-017-09049-9, 2017b.

Campeau, A., Bishop, K., Nilsson, M. B., Klemedtsson, L., Laudon, H., Leith, F. I., Öquist, M. G., and Wallin, M. B.: Stable carbon isotopes reveal soil-stream DIC linkages in contrasting headwater catchments, J. Geophys. Res.-Biogeo., 123, 149-167, https://doi.org/10.1002/2017JG004083, 2018. 
Castellano, M. J., Archontoulis, S. V., Helmers, M. J., Poffenbarger, H. J., and Six, J.: Sustainable intensification of agricultural drainage, Nat. Sustain., 2, 914-921, https://doi.org/10.1038/s41893-019-0393-0, 2019.

Crawford, J. T., Stanley, E. H., Dornblaser, M. M., and Striegl, R. G.: $\mathrm{CO}_{2}$ time series patterns in contrasting headwater streams of North America, Aquat. Sci., 79, 473-486, https://doi.org/10.1007/s00027-016-0511-2, 2017.

Deirmendjian, L., Anschutz, P., Morel, C., Mollier, A., Augusto, L., Loustau, D., Cotovicz, L. C., Buquet, D., Lajaunie, K., Chaillou, G., Voltz, B., Charbonnier, C., Poirier, D., and Abril, G.: Importance of the vegetation-groundwaterstream continuum to understand transformation of biogenic carbon in aquatic systems - A case study based on a pinemaize comparison in a lowland sandy watershed (Landes de Gascogne, SW France), Sci. Total Environ., 661, 613-629, https://doi.org/10.1016/j.scitotenv.2019.01.152, 2019.

Dinsmore, K. J. and Billett, M. F.: Continuous measurement and modeling of $\mathrm{CO}_{2}$ losses from a peatland stream during stormflow events, Water Resour. Res., 44, 11, https://doi.org/10.1029/2008WR007284, 2008.

Dinsmore, K. J., Wallin, M. B, Johnson, M. S., Billett, M. F., Bishop, K., Pumpanen, J., and Ojala, A.: Contrasting $\mathrm{CO}_{2}$ concentration discharge dynamics in headwater streams: A multicatchment comparison, J. Geophys. Res.-Biogeo., 118, 445-461, https://doi.org/10.1002/jgrg.20047, 2013.

Evans, C. and Davies, T. D.: Causes of Concentration/Discharge Hysteresis and its Potential as a Tool for Analysis of Episode Hydrochemistry, Water Resour. Res., 34, 129-137, https://doi.org/10.1029/97WR01881, 1998.

Gómez-Gener, L., Obrador, B., von Schiller, D., Marcé, R., CasasRuiz, J. P., Proia, L., Acuña, V., Catalán, N., Muñoz, I., and Koschorreck, M.: Hot spots for carbon emissions from Mediterranean fluvial networks during summer drought, Biogeochemistry, 125, 409-426, https://doi.org/10.1007/s10533-015-0139-7, 2015

Hall Jr., R. O. and Ulseth, A. J.: Gas exchange in streams and rivers, WIREs Water, 7, e1391, https://doi.org/10.1002/wat2.1391, 2020.

Halldin, S., Bergström, H., Gustafsson, D., Dahlgren, L., Hjelm, P., Lundin, L.C., Mellander, P. E., Nord, T., Jansson, P. E., Seibert, J., Stähli, M., Szilágyi Kishné, A., and Smedman, A. S.: Continuous long-term measurements of soil-plant-atmosphere variables at an agricultural site, Agr. Forest Meteorol., 98/99, 75102, https://doi.org/10.1016/S0168-1923(99)00149-5, 1999.

Holmqvist, M.: Avrinningsdynamik i fem små områden, Vattenbalans, recession, magasinskoefficient och dynamiskt vattenmagasin, MSc thesis, Uppsala University, 54 pp., 1998.

Hope, D., Palmer, S. M., Billett, M. F., and Dawson, J. J.: Variations in dissolved $\mathrm{CO}_{2}$ and $\mathrm{CH}_{4}$ in a first-order stream and catchment: an investigation of soil-stream linkages, Hydrol. Process., 18, 3255-3275, https://doi.org/10.1002/hyp.5657, 2004.

Humborg, C., Mörth, C. M., Sundbom, M., Borg, H., Blenckner, T., Giesler, R., and Ittekkot, V.: $\mathrm{CO}_{2}$ supersaturation along the aquatic conduit in Swedish watersheds as constrained by terrestrial respiration, aquatic respiration and weathering, Glob. Change Biol., 16, 1966-1978, https://doi.org/10.1111/j.13652486.2009.02092.x, 2010.
Hughes, R. M., Herlihy, A. T., and Kaufmann, P. R.: An Evaluation of Qualitative Indexes of Physical Habitat Applied to Agricultural Streams in Ten US States, J. Am. Water Resour. As., 46, 792-806, https://doi.org/10.1111/j.1752-1688.2010.00455.x, 2010 .

Johnson, M. S., Weiler, M., Couto, E. G., Riha, S. J., and Lehmann, J.: Storm pulses of dissolved $\mathrm{CO}_{2}$ in a forested headwater Amazonian stream explored using hydrograph separation, Water Resour. Res., 43, W11201, https://doi.org/10.1029/2007WR006359, 2007.

Johnson, M. S., Billett, M. F., Dinsmore, K. J., Wallin, M., Dyson, K. E., and Jassal, R. S.: Direct and continuous measurement of dissolved carbon dioxide in freshwater aquatic systems - methods and applications, Ecohydrology, 3, 68-78, https://doi.org/10.1002/eco.95, 2010.

Kokic, J., Wallin M. B., Chmiel H. E., Denfeld B. A., and Sobek S.: Carbon dioxide evasion from headwater systems strongly contributes to the total export of carbon from a small boreal lake catchment, J. Geophys. Res.-Biogeo., 120, 13-28, https://doi.org/10.1002/2014JG002706, 2015.

Kokic, J., Sahlée, E., Sobek, S., Vachon, D., and Wallin, M. B.: High spatial variability of gas transfer velocity in streams revealed by turbulence measurements, Inland Waters, 8, 461-473, https://doi.org/10.1080/20442041.2018.1500228, 2018.

Kyllmar, K., Forsberg, L. S., Andersson, S., and Mårtensson, K.: Small agricultural monitoring catchments in Sweden representing environmental impact, Agr. Ecosyst. Environ., 198, 25-35, https://doi.org/10.1016/j.agee.2014.05.016, 2014.

Laudon, H., Sjöblom, V., Buffam, I., Seibert, J., and Mörth, M.: The role of catchment scale and landscape characteristics for runoff generation of boreal streams, J. Hydrol., 344, 198-209, https://doi.org/10.1016/j.jhydrol.2007.07.010, 2007.

Leith, F. I., Dinsmore, K. J., Wallin, M. B., Billett, M. F., Heal, K. V., Laudon, H., Öquist, M. G., and Bishop, K.: Carbon dioxide transport across the hillslope-riparian-stream continuum in a boreal headwater catchment, Biogeosciences, 12, 1881-1892, https://doi.org/10.5194/bg-12-1881-2015, 2015.

Linefur, H., Norberg, L., Kyllmar, K., Andersson, S., and Blomberg, M.: Växtnäringsförluster i små jordbruksdominerade avrinningsområden 2016/2017, Uppsala, Sveriges lantbruksuniversitet, Ekohydrologi, 155, 55 pp., 2018.

Looman, A., Maher, D. T., Pendall, E., Bass, A., and Santos, I. R.: The carbon dioxide evasion cycle of an intermittent firstorder stream: contrasting water-air and soil-air exchange, Biogeochemistry, 132, 87-102, https://doi.org/10.1007/s10533-0160289-2, 2017.

Marcé, R., Obrador, B., Gómez-Gener, L., Catalán, N., Koschorreck, M., Arce, M. I., Singer, G., and von Schiller, D. Emissions from dry inland waters are a blind spot in the global carbon cycle, Earth-Sci. Rev. 188, 240-248, https://doi.org/10.1016/j.earscirev.2018.11.012, 2019.

Morel, B., Durand, P., Jaffrezic, A., Gruau, G., and Molenat, J. Sources of dissolved organic carbon during stormflow in a headwater agricultural catchment, Hydrol. Process., 23, 2888-2901, https://doi.org/10.1002/hyp.7379, 2009.

Natchimuthu, S., Wallin, M. B., Klemedtsson, L., and Bastviken, D.: Spatio-temporal patterns of stream methane and carbon dioxide emissions in a hemiboreal catchment in Southwest Sweden, Sci. Rep., 7, 39729, https://doi.org/10.1038/srep39729, 2017. 
Öquist, M. G., Wallin, M., Seibert, J., Bishop, K., and Laudon, H.: Dissolved inorganic carbon export across the soil/stream interface and its fate in a boreal headwater stream, Environ. Sci. Technol., 43, 7364-7369, https://doi.org/10.1021/es900416h, 2009.

Osborne, B., Saunders, M., Walmsley, D., Jones, M., and Smith, P.: Key questions and uncertainties associated with the assessment of the cropland greenhouse gas balance, Agr. Ecosyst. Environ., 139, 293-301, https://doi.org/10.1016/j.agee.2010.05.009, 2010.

Osterman, M.: Carbon dioxide in agricultural streams - magnitude and patterns of an understudied atmospheric carbon source, MSc thesis, Uppsala University, 58 pp., 2018.

Peter, H., Singer, G. A., Preiler, C., Chifflard, P., Steniczka, G., and Battin, T. J.: Scales and drivers of temporal $p \mathrm{CO}_{2}$ dynamics in an Alpine stream, J. Geophys. Res.-Biogeo., 119, 1078-1091, https://doi.org/10.1002/2013JG002552, 2014.

Ramankutty, N., Evan, A. T., Monfreda, C., and Foley, J. A.: Farming the planet: 1. Geographic distribution of global agricultural lands in the year 2000, Global Biogeochem. Cy., 22, https://doi.org/10.1029/2007GB002952, 2008

Raymond, P. A., Zappa, C. J., Butman, D., Bott, T. L., Potter, J., Mulholland, P., Laursen, A. E., Mcdowell, W. H., and Newbold, D.: Scaling the gas transfer velocity and hydraulic geometry in streams and small rivers, Limnol. Oceanogr., 2, 41-53, https://doi.org/10.1215/21573689-1597669, 2012.

Raymond P. A., Hartmann, R., Lauerwald, R., Sobek, S., Mcdonald, C., Hoover, M., Butman, D., Striegl, R., Mayorga, E., Humborg, C., Kortelainen, P., Durr, H., Meybeck, M., Ciais, P., and Guth, P.: Global carbon dioxide emissions from inland waters, Nature, 503, 355-359, https://doi.org/10.1038/nature12760, 2013.

Rhoads, B. L., Schwartz, J. S., and Porter, S.: Stream geomorphology, bank vegetation, and three-dimensional habitat hydraulics for fish in midwestern agricultural streams, Water Resour. Res., 39, https://doi.org/10.1029/2003WR002294, 2003.

Riml, J., Campeau, A., Bishop, K., and Wallin, M. B.: Spectral decomposition of high-frequency $\mathrm{CO}_{2}$ concentrations reveals soil-stream linkages, J. Geophys. Res.-Biogeo., 124, 3039-3056, https://doi.org/10.1029/2018JG004981, 2019.
Rocher-Ros, G., Sponseller, R. A., Bergström, A.-K., Myrstener, M., and Giesler, R.: Stream metabolism controls diel patterns and evasion of $\mathrm{CO}_{2}$ in Arctic streams, Glob. Change Biol., 26, 14001413, https://doi.org/10.1111/gcb.14895, 2020.

Royer, T. V. and David, M. B.: Export of dissolved organic carbon from agricultural streams in Illinois, USA, Aquat. Sci., 67, 465471, https://doi.org/10.1007/s00027-005-0781-6, 2005.

Sand-Jensen, K. and Staehr, P. A.: $\mathrm{CO}_{2}$ dynamics along Danish lowland streams: water-air gradients, piston velocities and evasion rates, Biogeochemistry, 111, 615-628, https://doi.org/10.1007/s10533-011-9696-6, 2012.

Seibert, J., Grabs, T., Köhler, S., Laudon, H., Winterdahl, M., and Bishop, K.: Linking soil- and stream-water chemistry based on a Riparian Flow-Concentration Integration Model, Hydrol. Earth Syst. Sci., 13, 2287-2297, https://doi.org/10.5194/hess-13-22872009, 2009.

Wallin, M. B.: Supplementary data for Carbon dioxide dynamics in an agricultural headwater stream driven by hydrology and primary production, available at: http://urn.kb.se/resolve?urn=urn: nbn:se:uu:diva-408793, last access: 7 May 2020.

Wallin, M. B., Öquist, M. G., Buffam, I., Billett, M. F., Nisell, J., and Bishop, K. H.: Spatiotemporal variability in the gas transfer coefficient $\left(\mathrm{KCO}_{2}\right)$ of boreal streams; implications for large scale estimates of $\mathrm{CO}_{2}$ evasion, Global Biogeochem. Cy., 25, GB3025, https://doi.org/10.1029/2010GB003975, 2011.

Wallin, M. B., Grabs, T., Buffam, I., Laudon, H., Ågren, A., Öquist, M. G., and Bishop, K.: Evasion of $\mathrm{CO}_{2}$ from streams - The dominant component of the carbon export through the aquatic conduit in a boreal catchment, Glob. Change Biol., 19, 785-797, 2013.

Wallin, M. B., Campeau, A., Audet, J., Bastviken, D., Bishop, K., Kokic, J., Laudon, H., Lundin, E., Löfgren, S., Natchimuthu, S., Sobek, S., Teutschbein, C., Weyhenmeyer, G., and Grabs, T.: Carbon dioxide and methane emissions of Swedish loworder streams - a national estimate and lessons learnt from more than a decade of observations, Limnol. Oceanogr., 3, 156-167, https://doi.org/10.1002/lo12.10061, 2018.

Weiss, R. F.: Carbon dioxide in water and seawater: The solubility of a non-ideal gas, Mar. Chem., 2, 203-215, https://doi.org/10.1016/0304-4203(74)90015-2, 1974. 